\title{
СІЛЬСЬКОГОСПОДАРСЬКИ НАУКИ
}

УДК 636.084/.087:631.147 (477)

DOI: 10.37000/abbsl.2021.99.17

\section{ОСНОВНІ ПЕРЕДУМОВИ І ВИМОГИ ЩОДО ПЕРЕХОДУ ГОСПОДАРСТВ УКРАЇНИ НА ВИРОБНИЦТВО ОРГАНІЧНИХ КОРМІВ ТА ГОДІВЛЮ СІЛЬСЬКОГОСПОДАРСЬКИХ ТВАРИН}

\author{
І. Різничук, С. Гурко, О. Кишлали, К. Мажиловська
}

Одеський державний аграрний університет

Проведено аналіз законодавчої та нормативної бази у сфері органічного виробництва, обігу та маркування органічної продукиї, встановлено вимоги до виробництва органічних кормів та годівлі тварин.

Зроблено висновок, щзо основною вимогою $з$ організації органічної годівлі сільськогосподарських тварин на сучасному етапі розвитку тваринництва, є розробка окремого підходу щзодо забезпечення потреби різних видів і виробничих груп тварин за обмінною енергією, поживними та біологічно активними речовинами, контроль раџіону за 24-40 показниками живлення.

Поставлено за мету розробити рецепти органічних кормових сумішей, впровадити їх виробництво та використання в годівлі різних видів сільськогосподарських тварин.

Ключові слова: корми, кормові матеріали, кормові добавки, органічна годівля тварин, годівля поросят, повнораціонні корми.

Постановка проблеми. На даний час в Україні виробництво органічної продукції здійснюється відповідно до Закону України «Про основні принципи та вимоги до органічного виробництва, обігу та маркування органічної продукції», «ПОРЯДКУ (детальних правил) органічного виробництва та обігу органічної продукції», «ПОРЯДКУ сертифікації органічного виробництва та/або обігу органічної продукції».

Державне регулювання виробництва органічної продукції передбачає:

$\checkmark$ встановлення порядку сертифікації органічного виробництва та/або обігу вітчизняної органічної продукції;

$\checkmark$ розвиток органічного ринку України, зростання обсягів виробництва органічної продукції, сертифікованої відповідно до законодавства України;

$\checkmark$ усунення торгових бар'єрів та визнання української органічної продукції на світовому ринку;

$\checkmark$ посилення довіри споживачів та імпортерів до українського органічного продукту як такого, що вироблений відповідно до законодавства, адаптованого до вимог права ЄС у сфері органічного виробництва;

$\checkmark$ покращення іміджу України як надійного виробника органічної продукції на міжнародному рівні.

Головним призначенням законодавчої та нормативної бази у сфері органічного виробництва є захист споживачів.

Проходження сертифікації органічного виробництва та отримання відповідно сертифіката, $\epsilon$ основою щодо маркування та реалізації продукції як органічна або «органічний продукт», отримати додаткову надбавку вартості за якість продукту.

Таким чином Порядок сертифікації органічного виробництва та обігу органічної продукції має вплив на суб'єктів господарювання, що займаються органічним виробництвом (або мають намір перейти на органічне виробництво), підприємства, установи, організації, що мають право на проведення сертифікації органічного виробництва, а також на громадян [5].

Акредитація сертифікаційних закладів проводиться Національним агентством з акредитації України. 
Зважаючи на сприятливі природні та кліматичні умови, географічне розташування Україна має значний потенціал для виробництва органічної продукції, іiї експорту, споживання на внутрішньому ринку [1].

Основними видами органічної продукції, яка виробляється в Україні є зернові, бобові та олійні культури, молоко, молочні продукти, крупи, борошно, а також соняшникова макуха i соняшникова олія.

Останнім часом спостерігається позитивна тенденція щодо зменшення частки експорту органічної продукції (близько 80 \%) до збільшення іiї споживання на внутрішньому ринку, підвищується попит суспільства на натуральні продукти.

Досвід країн СС показує, що заходів підвищення однієї лише продуктивності органічного виробництва недостатньо для розвитку всього ланцюга від виробника до споживача. Успіх органічної індустрії залежить від визнання органічної індустрії суспільством, тобто споживачами, їх довіри і попиту.

Отже, розвиток органічного ринку України повинен включати, 3 однієї сторони виробництво якісних органічних продуктів та нарощування каналів їх збуту, 3 іншої інформованість громадськості про переваги органічної продукції, особливо про позитивний вплив органічних продуктів на здоров'я людей.

По відношенню до органічного виробництва господарства поділяються на традиційні або неорганічні, знаходяться в процесі «конверсії», органічні, але не сертифіковані, сертифіковані як органічні [1].

Правила органічного виробництва передбачають два види діяльності:

1) Виробництво сільськогосподарської продукції (первинне виробництво, в тому числі збирання, підготовка, обробка, змішування, наповнення, пакування, переробка, відновлення та інші зміни стану продукції).

2) Обіг сільськогосподарської продукції (продаж (реалізація) товарів у межах митної території України, експорт, імпорт, переміщення (транспортування) або зберігання органічної продукції з метою продажу (реалізації), крім переміщення або зберігання маркованої органічної продукції для цілей реалізації кінцевому споживачу.

Аналіз актуальних досліджень. Загальними вимогами до органічного виробництва $є$ :

$\checkmark$ відокремлення у часі або просторі виробництва та зберігання органічної продукції, у тому числі ведення обліку такої продукції, від виробництва та зберігання неорганічної продукції $\mathrm{i}$ продукції перехідного періоду;

$\checkmark$ використання технологій, що відповідають вимогам законодавства у сфері органічного виробництва, обігу та маркування органічної продукції;

$\checkmark$ використання технологій, що не завдають шкоди здоров'ю людей, рослинам, благополуччю тварин, запобігають забрудненню навколишнього природного середовища або мінімізують його;

$\checkmark$ використання води як інгредієнта органічної продукції, що відповідає вимогам, встановленим законодавством до води питної;

$\checkmark$ заборона змішування одних і тих самих органічних і неорганічних інгредієнтів в одному органічному продукті.

У процесі органічного виробництва забороняється застосування генетично модифікованих організмів, синтетичних речовин (агрохімікатів, пестицидів, мінеральних азотних добрив), антибіотиків, гормональних препаратів та інших стимуляторів росту для підгодівлі тварин, транквілізаторів, іонізуючого випромінювання, гідропонних методів вирощування рослин [2].

Основними вимогами до виробництва органічних кормів є:

$\checkmark$ кормові матеріали, кормові добавки та інгредієнти, що використовуються у виробництві кормів, а також будь-які методи переробки повинні застосовуватися на засадах належної виробничої практики [4].

$\checkmark$ виробництво та зберігання кормів мають грунтуватися на основі впровадження та актуалізації процедур, що базуються на принципах системи аналізу небезпечних факторів та контролю у критичних точках (НАССР), [3;4]. 
$\checkmark$ виробництво кормів повинне проводитись 3 органічної сировини, крім випадків, коли на ринку відсутні такі органічні кормові матеріали. При цьому сировина, що використовується у виробництві органічних кормів, не повинна містити одночасно один і той самий органічний i неорганічний інгредієнт;

$\checkmark$ кормові матеріали, що використовуються в органічному виробництві, не можуть оброблятися синтетичними розчинниками;

$\checkmark$ зведення до мінімуму використання кормових добавок та допоміжних засобів, крім випадків, коли це необхідно для технологічних або зоотехнічних потреб чи для конкретних цілей годівлі;

$\checkmark$ використання переважно біологічних, механічних і фізичних методів виробництва;

$\checkmark$ вміст у кормі не більше одного інгредієнта сільськогосподарського походження, виробленого у перехідний період;

$\checkmark$ ведення обліку та документування всіх технологічних процесів з виробництва кормів;

$\checkmark$ застосування необхідних заходів для забезпечення ідентифікації та простежуваності кожної партії кормів і запобігання змішуванню або підміні неорганічними кормовими матеріалами [2;4].

Основними вимогами стосовно годівлі тварин $є$ :

$\checkmark$ використання органічних кормів для годівлі тварин. Неорганічні кормові матеріали рослинного, тваринного i мінерального походження, кормові добавки, продукти, що застосовуються для годівлі тварин та як технологічні добавки, можуть використовуватися лише у разі, коли вони внесені до переліку речовин (інгредієнтів, компонентів);

$\checkmark$ постійний доступ поголів'я до пасовищ, якщо дозволяють погодні умови та стан грунту, або зелених та грубих кормів;

$\checkmark$ заборонено застосування антибіотиків, гормонів, кокцидіостатиків, гістомонстатиків та синтетичних амінокислот для стимулювання росту або продуктивності тварин;

$\checkmark$ раціон тварин встановлюється залежно від віку, маси тіла, стану здоров'я тварин та виду корму. Забороняється примусова відгодівля тварин;

$\checkmark$ для годівлі травоїдних тварин, крім періоду, коли тварин переводять із зимового утримання на літнє, використовуються органічні корми, не менш як 50 відсотків яких вироблені в господарстві, де утримуються такі тварини, або в іншому господарстві, яке здійснює виробництво органічної продукції, переважно того ж регіону. Для свиней та птиці такий показник повинен становити 20 відсотків, кролів - 70 відсотків;

$\checkmark$ усі молоді ссавці повинні вигодовуватися природним молоком, переважно материнським. Мінімальний строк такого вигодовування для великої рогатої худоби становить три місяці, для овець і кіз - 45 днів, для свиней - 40 днів;

$\checkmark$ система вирощування для жуйних тварин повинна грунтуватися переважно на випасі 3 урахуванням доступності пасовищ у різні пори року. Не менш як 60 відсотків сухої речовини у добовому раціоні травоїдних тварин повинні становити грубі органічні корми, сінаж чи силос. Для тварин молочного напряму продуктивності такий показник може бути зменшений до 50 відсотків на початку лактації на період не більше трьох місяців;

$\checkmark$ грубі, зелені або сухі органічні корми чи силос повинні додаватися до щоденного раціону свиней.

$\checkmark$ заборонено утримувати тварин у таких умовах або на такій годівлі, що може призвести до анемії;

$\checkmark$ практика відгодівлі повинна бути зворотною на будь-якому етапі вирощування $[2,5]$.

Отже, підсумовуючи вищеозначене можна зробити висновок, що в Україні створена законодавча та нормативна база у сфері органічного виробництва, обігу та маркування органічної продукції, встановлено вимоги до виробництва органічних кормів та годівлі тварин. При цьому основною вимогою з організації органічної годівлі сільськогосподарських тварин на сучасному етапі розвитку тваринництва, $є$ розробка окремого підходу щодо забезпечення потреби різних 
видів і виробничих груп тварин за обмінною енергією, поживними та біологічно активними речовинами, контроль раціону за 24-40 показниками живлення.

3 огляду на вищеозначене, нами поставлено за мету розробити рецепти органічних кормових сумішей, впровадити їх виробництво та використання в годівлі різних видів сільськогосподарських тварин.

Мета роботи. Предметом щодо вибору тематики досліджень $є$ актуальність проблеми раціональної годівлі тварин у відповідності до вимог органічного виробництва.

Метою дослідження було проаналізувати основні вимоги стосовно органічної годівлі поросят-сисунів та розкрити особливості їх травлення у ранньому віці, розробити схему годівлі поросят-сисунів віком 1-42 днів, скласти рецепти органічних кормових сумішей для поросят живою масою від 1 до 18 кг з використанням кормових матеріалів та кормових добавок, які використовуються для органічної годівлі тварин у відповідності до переліку речовин, що дозволяється використовувати у процесі органічного виробництва.

Виклад основного матеріалу. Результати досліджень. Визначальним етапом у технологічному процесі органічного вирощування поросят $\epsilon$ використання тваринами природного, переважно материнського молока в період від народження до 40-денного віку, раннє привчання до органічних повнораціонних кормів та досягнення оптимальної живої маси на період відлучення.

Відомо, що травна система поросят пристосована до перетравлення молочних кормів. Перш за все, починають діяти ферменти, які розщеплюють лактозу, молочний жир і молочний протеїн. При народженні в поросят дуже невисокий рівень вироблення ферментів, які розщеплюють органічні речовини рослинного походження (крохмаль, цукор і протеїни). Вироблення таких ферментів починається з надходженням в травну систему поросят рослинних кормів. Ферменти, які розщеплюють молочний жир, у перші дні життя поросят $є$ неспецифічними, тобто вони можуть достатньо добре розщеплювати і рослинні жири.

У перші три тижні життя у поросят виробляється відносно невелика кількість шлункового соку, яка потім поступово підвищується із збільшенням поїдання корму.

3 огляду на вищеозначене, зволікання з підгодівлею поросят у перші дні після народження повнораціонним гранульованим або розсипним комбікормом, стримує вироблення кишкового соку і концентрацію в шлунку соляної кислоти, що є однією із основних причин розладу травлення у поросят-сисунів.

Недостатньо підкислена і перетравлена в шлунку кормова маса надходить в дванадцятипалу кишку, де інтенсивно починають розмножуватися бактерії E.coli, які попадаючи в товстий кишечник, спричиняють розлад травлення у поросят. Крім цього, при значеннях рН більше 4 погіршується перетравлення протеїну, оскільки найбільша активність протеаз досягається в більш кислому середовищі [6].

Таким чином, враховуючи основні вимоги стосовно організації органічної годівлі поросятсисунів, забезпеченість тварин поживними речовинами материнського молока за декадами підсисного періоду та їх фізіологічні особливості травлення, нами розроблена схема годівлі поросят-сисунів до 42-денного віку 3 використанням повнораціонних гранульованих або розсипних органічних кормів, що зазначена в таблиці 1.

Згідно схеми, що зазначена в таблиці 1 можна побачити, що вже 3 перших днів життя поросят-сисунів привчають до споживання повнораціонного корму, насипаючи його в спеціальні плоскі годівниці, які ставлять безпосередньо біля лігва поросят. У період із 4 по 7 день поросятамсисунам згодовують 10 г, з 8 по 14 - 30 г повнораціонного комбікорму на голову за добу. Сухий корм змінюють часто, насипаючи його в годівниці невеликими порціями, щоб стимулювати його використання поросятами. Також з перших днів життя поросята повинні мати вільний доступ до свіжої питної води. При цьому необхідно слідкувати за тим, щоб через 1 годину після роздавання комбікорму годівниця була порожньою. Після видалення залишків корму годівниці і напувалки ретельно очищають і миють.

У період з 15 по 21 день поросятам-сисунам згодовують 75, з 22 по 28 - 150, з 29 по 35 325 , а із 36 по 42 день - 300 г повнораціонного корму, на голову за добу.

Годівля поросят у цей період триразова. Перед наступною годівлею поросят годівниця має бути порожньою. 
Відлучення поросят проводять у 42 добовому віці. У день відлучення свиноматку вранці не годують, не обмежуючи доступу до води, а поросятам роздають повнораціонний корм 3 розрахунку 375 г на голову за добу. Після цього, через 2-3 години від часу годівлі поросят, свиноматку зі станка виганяють, а поросята залишаються в ньому без свиноматки до 49-денного віку. У перші 7 днів після відлучення від свиноматок незмінною $є$ годівля поросят повнораціонним кормом, який вони одержували в підсисний період.

Усього за підсисний період тварини споживають в якості підгодівлі до материнського молока 5,5 кг повнораціонного гранульованого або розсипного комбікорму для поросят 1-18 кг.

Таблиця 1. Схема годівлі поросят-сисунів у віці від 1 до 42 днів за органічного виробництва свинини

\begin{tabular}{|c|c|c|c|}
\hline $\begin{array}{l}\text { Вiк, } \\
\text { днів }\end{array}$ & $\begin{array}{c}\text { Жива } \\
\text { маса, } \\
\text { кг }\end{array}$ & $\begin{array}{c}\text { ПК } \\
\text { для поросят } \\
1-18 \text { кГ } \\
\end{array}$ & Умови годівлі \\
\hline 1 & 1,5 & - & $\begin{array}{c}\text { Молозиво свиноматки } \\
\text { не пізніше, ніж через } 1,5-2,0 \text { годин після народження }\end{array}$ \\
\hline 2 & - & - & Молозиво свиноматки \\
\hline 3 & - & - & $\begin{array}{c}\text { Молозиво свиноматки } \\
\text { Вільний доступ до води }\end{array}$ \\
\hline 4-7 & - & $10(40)$ & $\begin{array}{c}\text { ПК для поросят 1-18 кг } \\
\text { Роздавання - } 4 \text { рази за добу } \\
\text { Через одну годину годівниця має бути порожньою }\end{array}$ \\
\hline $8-14$ & & 30 (210) & $\langle\langle\rangle\langle\langle\rangle\langle\langle\rangle\rangle$ \\
\hline $15-21$ & 6 & $75(525)$ & $\begin{array}{c}\text { ПК для поросят 1-18 кг } \\
\text { Роздавання - } 3 \text { рази за добу } \\
\text { Перед наступною годівлею годівниця має бути порожньою } \\
\text { Обмежити доступ поросят до комбікорму, який згодовують } \\
\text { підсисним свиноматкам }\end{array}$ \\
\hline $22-28$ & 8 & $150(1050)$ & $\langle\langle\rangle\langle\langle\rangle\langle\langle\rangle$ \\
\hline $29-35$ & - & $225(1575)$ & $\langle\langle\rangle\langle\langle\rangle\langle\langle\rangle\rangle$ \\
\hline $36-42$ & 12 & $300(2100)$ & $\langle\langle\rangle\langle\langle\rangle\langle\langle\rangle$ \\
\hline Разом, кг & - & $\mathbf{5 , 5}$ & - \\
\hline
\end{tabular}

*ПК 1-12 кг - повнораціонний розсипний комбікорм для поросят живою масою 1-18 кг. **ПГК - повнораціонний гранульований комбікорм для поросят живою масою 1-18 кг.

Отже, схема годівлі поросят-сисунів у віці від 1 до 42 днів за органічного виробництва свинини враховує період молочності свиноматок, фізіологічні особливості травлення свиней раннього віку, забезпечує раціональне використання повнораціонних гранульованих або розсипних комбікормів, запобігає надмірній втраті живої маси підсисних свиноматок, відповідає основним вимогам стосовно органічної годівлі тварин вищеозначеної виробничої групи.

Таблиця 2.Рецепти органічних кормових сумішей

\begin{tabular}{|c|c|c|c|c|c|c|}
\hline \multirow{3}{*}{ Показники } & \multicolumn{6}{|c|}{ Склад комбікорму } \\
\hline & \multicolumn{2}{|c|}{ Bapiaнт 1} & \multicolumn{2}{|c|}{ Bapiaнт 2} & \multicolumn{2}{|c|}{ Bapiaнт 3} \\
\hline & $\%$ & кГ & $\%$ & кГ & $\%$ & кг \\
\hline Пшениця & 25 & 250 & 30 & 300 & 35 & 350 \\
\hline Ячмінь & 18 & 180 & 18 & 180 & 18 & 180 \\
\hline Кукурудза & 25 & 250 & 25 & 250 & 25 & 250 \\
\hline Макуха соєва & 25 & 250 & 20 & 200 & 15 & 150 \\
\hline $\begin{array}{l}\text { Білково-вітамінна добавка «Про Органік» } \\
\text { для поросят } 1-18 \text { кг } 5 \% \text { «Годівля Нова» }\end{array}$ & 5 & 50 & 5 & 50 & 5 & 50 \\
\hline Соєва олія, фуз олійний & 2 & 20 & 2 & 20 & 2 & 20 \\
\hline Разом & 100 & 1000 & 100 & 1000 & 100 & 1000 \\
\hline
\end{tabular}

Рецепти органічних кормових сумішей для поросят живою масою від 1 до 18 кг 3 використанням кормових матеріалів та кормових добавок, які використовуються для органічної 
годівлі тварин у відповідності до переліку речовин, що дозволяється використовувати у процесі органічного виробництва зазначені в таблицях 2 і 3.

Таблиця 3.Рецепти органічних кормових сумішей

\begin{tabular}{|l|c|c|c|c|c|c|}
\hline \multirow{2}{*}{ Показники } & \multicolumn{7}{c|}{ Склад комбікорму } \\
\cline { 2 - 8 } & \multicolumn{2}{|c|}{ Bapiaнт 1 } & \multicolumn{2}{c|}{ Bapiaнт 2 } & \multicolumn{2}{c|}{ Варіант 3 } \\
\cline { 2 - 7 } & $\%$ & кг & $\%$ & кг & $\%$ & кг \\
\hline Пшениця & 20 & 200 & 25 & 250 & 30 & 300 \\
\hline Ячмінь & 18 & 180 & 18 & 180 & 18 & 180 \\
\hline Кукурудза & 25 & 250 & 25 & 250 & 25 & 250 \\
\hline Макуха соєва & 25 & 250 & 20 & 200 & 15 & 150 \\
\hline Макуха соняшникова & 5 & 50 & 5 & 50 & 5 & 50 \\
\hline $\begin{array}{l}\text { Білково-вітамінна добавка «Про Органік» } \\
\text { для поросят 1-18 кг 5\% «Годівля Нова» }\end{array}$ & 5 & 50 & 5 & 50 & 5 & 50 \\
\hline Соняшникова або соєва олія, фуз олійний & 2 & 20 & 2 & 20 & 2 & 20 \\
\hline \multicolumn{1}{|c|}{ Разом } & 100 & 1000 & 100 & 1000 & 100 & 1000 \\
\hline
\end{tabular}

Визначальним при цьому має стати дотримання оптимального співвідношення незамінних амінокислот у раціонах для поросят у відповідності до вимог [7,8,9], що зазначені в таблиці 4.

Таблиця 4.Оптимальне співвідношення незамінних амінокислот у раціонах поросят, \% до лізину

\begin{tabular}{|c|c|c|c|c|c|c|c|c|c|c|}
\hline Група свиней & $\stackrel{\Xi}{\Xi}$ & $\stackrel{\text { 尸゙}}{\sum^{ \pm}}$ & 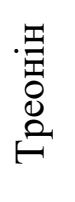 & 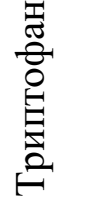 & 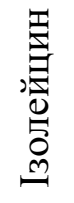 & 莺 & 志 & $\stackrel{+}{+}$ & $\begin{array}{l}\text { 当 } \\
\text { 岕 }\end{array}$ & $\begin{array}{l}\text { 䍐 } \\
\text { 完 }\end{array}$ \\
\hline Поросята до 20 кг & 100 & 60 & 67 & 20 & 60 & 110 & 39 & 120 & 75 & 42 \\
\hline
\end{tabular}

Висновки і перспективи подальших досліджень. Визначальним етапом у технологічному процесі органічного вирощування поросят $є$ використання тваринами природного, переважно материнського молока в період від народження до 40-денного віку, раннє привчання до органічних повнораціонних кормів та досягнення оптимальної живої маси на період відлучення.

Схема годівлі поросят-сисунів у віці від 1 до 42 днів за органічного виробництва свинини враховує період молочності свиноматок, фізіологічні особливості травлення свиней раннього віку, забезпечує раціональне використання повнораціонних гранульованих або розсипних комбікормів, запобігає надмірній втраті живої маси підсисних свиноматок, відповідає основним вимогам стосовно органічної годівлі тварин вищеозначеної виробничої групи.

Рецепти органічних кормових сумішей для поросят живою масою від 1 до 18 кг розроблено 3 використанням кормових матеріалів та кормових добавок, які використовуються для органічної годівлі тварин у відповідності до переліку речовин, що дозволяється використовувати у процесі органічного виробництва.

При розробці рецептів органічних повнораціонних кормів для поросят живою масою 1-18 кг одним із визначальних заходів $\epsilon$ встановлення необхідного рівня їх протеїнового живлення та дотримання оптимального співвідношення незамінних амінокислот (\% до лізину).

На даний період проводяться дослідження щодо встановлення оптимальних рецептів органічних кормових сумішей для поросят 1-18 кг та їх подальшого впровадження у виробництво.

\section{Список використаних джерел}

1. Довідник міжнародних стандартів до органічного виробництва / Навчальнокоординаційний центр сільськогосподарських дорадчих служб. За редакцією Капштика М.В., Котирло О.О. К.: СПД Горобець Г.С. 2007. 356 с.

2. Закон України «Про основні принципи та вимоги до органічного виробництва, обігу та маркування органічної продукції» № 2740 від 03.07.2019 р. [Електронний ресурс]: Режим доступу: https://zakon.rada.gov.ua/. 
3. Закон України «Про безпечність та гігієну кормів» № 2639-VIII від 06.08.2019 p. [Електронний ресурс]: Режим доступу: https://zakon.rada.gov.ua/.

4. ПОРЯДОК (детальні правила) органічного виробництва та обігу органічної продукції № 970 від 23.10.2019 р. [Електронний ресурс]: Режим доступу: https://zakon.rada.gov.ua/.

5. ПОРЯДОК сертифікації органічного виробництва та/ або обігу органічної продукції № 1032 від 21.10.2020 р. [Електронний ресурс]: Режим доступу: https://zakon.rada.gov.ua/.

6. Різничук I. Ф. Нагірняк I. Б. Схема годівлі поросят-сисунів при інтенсивному виробництві свинини. Тваринництво України. 2015. № 12. С. 33-37.

7. Futterberechnung für Schweine. Freising: Institut für Tierernährung und Futterwirtschaft, 2004. № 14. P. 9.

8. Ferkelfütterung. Aktuelle Versuche Versuchsergebnisse 2004. Freising: Institut für Tierernährung und Futterwirtschaft, 2004. 50 p.

9. Futterberechnung für Schweine. Bayerische Landesanstalt für Tierzucht, 1996. № 10. P. 7.

\section{ОСНОВНЫЕ ПРЕДПОСЫЛКИ И ТРЕБОВАНИЯ ПО ПЕРЕХОДУ ХОЗЯЙСТВ УКРАИНЫ НА ПРОИЗВОДСТВО ОРГАНИЧЕСКИХ КОРМОВ И КОРМЛЕНИЕ СЕЛЬСКОХОЗЯЙСТВЕННЫХ ЖИВОТНЫХ}

Ризничук И., Гурко Е., Кишлалы О., Мажиловськая К.

Проведен анализ законодательной и нормативной базы в сфере органического производства, обращения и маркировки органической продукиии, установлены требования к производству органических кормов и кормления животных.

Сделан вывод, что основным требованием по организаџии органического кормления сельскохозяйственных животных на современном этапе развития животноводства, является разработка отдельного подхода по обеспечению потребности различных видов $u$ производственных групп животных по обменной энергии, питательнылм и биологически активным веществам, контроль рациона по 24-40 показателям питания.

Поставлена иель разработать рецепты органических кормовых смесей, внедрить их производство и использование в кормлении различных видов сельскохозяйственных животных.

Ключевые слова: корма, кормовые материалы, кормовые добавки, органическое кормление животных, кормление поросят, полнорационные корма.

\section{BASIC PRECONDITIONS AND REQUIREMENTS FOR THE TRANSITION OF UKRAINIAN FARMS TO THE PRODUCTION OF ORGANIC FEED AND FEEDING OF} FARM ANIMALS

Riznychuk I., Hurko Ye., Kyshlaly O., Mazhilovskaya K.

The analysis of the legislative and regulatory framework in the field of organic production, circulation and labeling of organic products, the requirements for the production of organic feed and animal feed.

It is concluded that the main requirement for the organization of organic feeding of farm animals at the present stage of livestock development is to develop a separate approach to meet the needs of different species and production groups of animals for metabolic energy, nutrients and biologically active substances, diet control for 24-40 nutrients.

The aim is to develop recipes for organic feed mixtures, to introduce their production and use in the feeding of various species of farm animals.

Key words: feed, feed materials, feed additives, organic feeding of animals, feeding of piglets, complete feed. 